\title{
Is Japan's Retail Sector Truly Distinctive?
}

\author{
David Flath \\ Tatsuhiko Nairu
}

Working Paper No. 72

\author{
Professor David Flath \\ Department of Economics \\ North Carolina State University \\ Professor Tatsuhiko Nairu \\ Associate Professor of Marketing \\ School of Business Administration \\ Nanzan University
}

\author{
Working Paper Series \\ Center on Japanese Economy and Business \\ Graduate School of Business \\ Columbia University \\ November 1992
}




\title{
Is Japan's Retail Sector Truly Distinctive?
}

\author{
David Flath* and Tatsuhiko Nariu*
}

\begin{abstract}
$\underline{\text { Abstract }}$
Based on statistical analysis of data for 17 countries, Japan's ubiquity of retail stores is largely predicted by its relatively small dwellings, geographic concentration, and high number of commercial vehicles relative to private ones, controlling for the effects of population density. All are factors that economic theory associates with density of retail outlets. This evidence refutes the widespread view that Japan's structure of retail trade is determined by cultural, historical, and regulatory factors unique to Japan.
\end{abstract}

*Professor, Department of Economics, North Carolina State University, Raleigh, NC 27695-7506, tel. (919)515-2472. FAX: (919)515-3787.

"Associate Professor of Marketing, School of Business Administration, Nanzan University, 18 Yamazato-cho, Showa-ku, Nagoya 466 JAPAN, tel. (52)832-3111, ext. 438. FAX: 81-52-833-6986. 


\section{Is Japan's Retail Sector Truly Distinctive?}

\section{Introduction}

Recent commentary is unequivocal in describing Japan's retail sector as distinct among the developed countries. Japan has far more retail stores per person than the U.S. or than most all of the European countries. Excluding eating and drinking establishments, Japan in the early 1980s had 14.3 stores per thousand persons compared to the U.S.: 6.1 , the U.K.: 6.2 , W.Germany: 6.6 , and France: 10.3. It is also often remarked that Japan's marketing system is distinguished by its long and convoluted wholesale distribution channels. But within Japan, kinds of business for which retail stores are particularly great in number compared to the U.S. have been shown to have more complex wholesale distribution channels (Nariu and Flath, forthcoming), which suggests that the ubiquity of stores is the essential difference betweeen the marketing system of Japan and that of other countries. The ubiquity of small, so-called "papa-mama" stores in Japan has been related to the long history of government protection of small stores from competition with larger ones (McCraw and O'Brien, 1986), has been related to labor market discrimination against women and the aged (Patrick and Rholen, 1987), and has been further interpreted as an anachronistic holdover from Japan's preindustrial past.

If Japan's retail sector truly is so distinctive then in statistical analysis of international differences in numbers of stores per person Japan will be an outlier. It is our main object to conduct precisely such a statistical analysis. Contrary to the widely held view, Japan's large number of stores in fact does not render it a regression outlier. Japan's ubiquity of stores is well predicted by the limited space of its dwellings, its paucity of privately owned vehicles, abundance of commercial vehicles, and the short length of the country, controlling for population density. All are variables related 
either to households' costs of storing and transporting goods or to the costs of restocking a multiplicity of stores, and therefore are related to the economic advantages of a retail sector comprising a large number of stores.

\section{The Economics of Retail Structure}

There are two basic models of retail structure. The first basic model, the social optimality model, presumes that the density of retail stores is that which minimizes the combined storage and transport costs of households and of the distribution sector. Here pricing is not modelled explicitly but it is presumed that the retail sector itself fully captures incremental savings of household storage and reorder cost that result from a greater density of outlets (perhaps by employing some form of multipart pricing). Flath (1990) takes this approach. The second basic model, the Nash pricing with free-entry model, explicitly represents the pricing choices of retailers as the outcome of a noncooperative game. In this model the density of retail outlets is the greatest consistent with positive profits. Capozza and Van Order (1978), Heal (1980), Gabszewicz and Thisse (1986) and others adopt this approach. Not surprisingly, when retail pricing is modelled as a Bertrand game with free entry, the equilibrium density of outlets need not be socially optimal. The two basic models are in this sense distinct. Nevertheless, the two models are observationally equivalent in that their comparative statics are the same. In both models, exogenous factors that raise household costs of transporting or storing goods favor a greater profusion of stores, while factors that raise the retail sector's costs of storing and restocking goods favor fewer stores.

In the social optimality model, having more stores shortens the distance between the representative household and its nearest store and lowers households' costs of transporting goods. 
And the lower transport costs induce households to shop more frequently for smaller loads to achieve still further economies on storage of nondurables. However, having more stores increases the stores' combined inventory costs because it is more costly to restock many stores than it is a few. The socially optimal density of stores is accordingly greater where households are less efficient at storage and reorder or the distribution sector more efficient at storage and reorder. Also greater population density shortens the distance between house and store for any given number of stores per household and is similar in its effect on the socially optimal number of stores per household to other factors, such as car ownership, that also reduce household shopping costs: Greater population density favors the social optimality of a lower number of stores per household.

In the Nash pricing with free entry model, factors that raise all households' costs of storing and transporting goods lead the households to offer a higher premium to retailers who locate closer to their dwellings, which makes a greater profusion of stores profitable. Factors that raise retailers' storage and reorder costs make it less profitable to accommodate households' preference for shorter shopping trips and lower the profitability of a profusion of stores. The comparative statics are therefore the same as for the social optimality model. ${ }^{1}$

In the following we propose proxies for the storage and transport costs of households and of retailers for a number of countries including Japan, and relate these proxies and population density to

${ }^{1}$ One way of stating the reason why the comparative statics of the two models are qualitatively the same is this. The socially optimal density of stores is that for which the marginal increase in retailers' inventory costs as stores proliferate equals the marginal reduction in the average households' inventory costs. Under the assumption of Nash pricing, the greatest density of stores consistent with nonnegative profits is that for which the marginal increase in retailers' inventory costs as stores proliferate just equals the marginal reduction in the marginal households' inventory costs. The marginal households are those just indifferent between buying from one store and another one. 
numbers of stores per person.

\section{Data and Analytic Approach}

As the previous discussion has made clear, the number of retail stores depends upon the households' costs of storing and transporting goods, on the distribution sector's storage and reorder costs, and upon population density. In conducting empirical analysis, these various mathematical functions cannot be directly measured. Only proxies are available. From United Nations Statistical Yearbook (1983/84), we draw for a sample of countries including Japan: population, land area, population density (POP/KM2: population per $10,000 \mathrm{~m}^{2}$ ), and density of retail stores other than eating and drinking establishments (STORES: retail stores per thousand persons). For the other variables needed only less perfect proxies are available. From the same source we observe numbers of private vehicles and numbers of commercial vehicles which we use to construct proxies for households' and businesses' costs of transporting goods: (CARS: private vehicles per person) and (TRUCKS: commercial vehicles per person). That is we presume that in countries where private vehicle ownership is more extensive households have lower costs of transporting goods from stores to dwellings, and in countries where commercial vehicles are more extensive the costs of restocking stores are less. Furthermore, where the square root of a country's land area (LENGTH) is great so that point of production is apt to be a great distance from point of final sale, the costs of restocking stores are further increased.

As a proxy for household storage costs we employ average size of dwelling, on the presumption that greater space means lower storage costs. In the UN statistics for a number of countries, floor space per dwelling (FLOORSP) for new construction is reported (Table 157). It would have been 
preferable to have floor space for existing dwellings. However the size of newly constructed dwellings probably varies across countries somewhat in proportion to the size of existing ones.

Unavailability of data for some countries limits the number of observations in the regression analysis to a small sample. Of course population and land area were available for all countries. However,

(1) For some countries the reported numbers of retail stores are limited to those having more than a certain number of employees or more than a certain value of annual sales. ${ }^{2}$

(2) For some countries the floor space of newly constructed or existing dwellings was not available and could not be calcuated. ${ }^{3}$

(3) For some countries the numbers of private or commercial vehicles were not reported. These restrictions leave 19 countries for which complete statistics are reported, but six of these were of the communist block. Also, the 19 do not include the U.S., U.K., France, W. Germany and some other important developed countries of the world. We have therefore augmented our sample with observations taken from different sources: Seifu shiryo nado fukyu chosa-kai, gekkan seifu shiryo (association of surveys of data such as disseminated by governments, monthly report of government data), no. 203, 1991, for floor space of existing dwellings for France, W. Germany, U.K., and the U.S.. Also from Maruyama, et al. (1991, Table 1-1, p. 7) we have collected numbers of stores per person for W. Germany, U.K., and the U.S..

\footnotetext{
${ }^{2}$ For instance, for Australia only retail stores having annual sales in excess of 50,000 Aus. dol. are counted. In Thailand only stores with more than 5 employees are counted.

${ }^{3}$ For Finland and the UK, the volume of newly constructed dwellings was reported rather than the floor space. For these countries we assumed a ceiling height of 4 meters and converted the figures to floor space equivalents.
} 
The six communist countries in the sample have rather fewer retail stores per person than any of the other countries. We exclude them from the sample. After augmenting the sample as just described this leaves a total of 17 countries for regression analysis. The raw data is reported fully in the appendix. In the regression analysis the raw data is first converted to natural logarithms. The names, descriptions, sources, means and standard deviations of all the variables used in the regressions are included in Table 1.

\section{Results}

The OLS regression estimates are reported in Table 2. There are two important results. The first result is that all the estimates are consistent with our predictions. Countries in which households have limited storage space (LFLOORSP is small) or lack motor vehicles (LCARS is small), or in which retailers are apt to be near producers (LLENGTH is small), or have access to a surfeit of trucks for restocking their shelves (LTRUCKS is great), tend to have more stores per person, controlling for population density. Countries with greater population density (LPOP/KM 2 is great) tend to have fewer stores per person, ceteris paribus. In spite of the very small size of the sample several of the t-statistics are highly significant. Only the estimated coefficients on population

density $(L P O P / K M 2)$ and square root of land area $(L L E N G T H)$, which is our proxy for distance from point of production to point of sale, are not significant at the $5 \%$ level and even these are significant at the $10 \%$ level.

The second important result is that Japan is not a regression outlier. The regression equation (with Japan excluded) predicts the value for Japan of 13.36 stores per thousand persons compared to the actual value of 14.34 , well within the prediction interval at the $95 \%$ confidence level:(8.40, 
21.25). In fact, the predicted value for Japan is sufficiently close to the actual value that it is contained by a prediction interval so narrow that it can only be maintained with $30 \%$ confidence. ${ }^{4}$ Also the regression coefficients are little affected by the exclusion of Japan, as can be seen by comparing the two columns of Table 2, which is a further indication that Japan is not a regression outlier.

These findings reinforce that of Flath (1990) that Japan's Large Store Law is not the essential reason for Japan's relative profusion of retail stores. Rather, Japan's ubiquity of retail stores has the following explanation. First, Japanese dwellings tend to be rather small and confined so that household storage space is limited and costly. This contributes to Japan's high density of retail stores selling nondurable goods. Actually, Greece and France as well as Japan all have rather small dwellings and all have relatively many retail stores per person.

Second, private motor vehicles per person in Japan is among the lowest of the developed countries, only the U.K. and Ireland having fewer cars per person among the countries of our sample. By contributing to high household costs of transporting goods from store to dwelling, the low incidence of car ownership further promotes a greater density of retail outlets.

Third, Japan has among the greatest number of commercial vehicles per person, only the U.S. having more among the countries in our sample. Furthermore, Japan is geographically small with

${ }^{4}$ The prediction interval for the logarithmic variable LSTORES for Japan is:

$\left[2.592-t_{\text {d.f. }=10, \text { sig. }=\alpha / 2}(0.179) \sqrt{1.476} \leq L S T O R E S:\right.$ Japan $\left.\leq 2.592+t_{\text {d.f }=10, \text {,ig. }=\alpha / 2}(0.179) \sqrt{1.476}\right]$.

Here 2.592 is the predicted value of LSTORES (Its observed value is 2.663). Also $0.179=s$ is the estimated standard error of the disturbance and $0.476=h$ is the value of the "hat" variable, the component of the variance of the prediction error that is due to the sampling errors of the coefficent estimators. See Theil (1971), pp. 134-5 for derivation of the prediction interval. 
most of its population residing along the coastal plains. By causing the costs of restocking stores to be low, these factors further contribute to Japan's profusion of retail stores.

\section{Conclusion}

Japan's ubiquity of retail stores shifts storage and reorder activities away from Japanese consumers who are relatively inefficient at these activities and towards retailers who are relatively efficient at them. Japan's ubiquity of stores is not the result of backwardness, nor a reflection of historical, cultural or regulatory factors unique to Japan. 
References

Capozza, Dennis R. and Robert Van Order (1978). "A Generalized Model of Spatial Competition," The American Economic Review, Vol. 68, pp. 896-908.

Flath, David (1990). "Why Are There So Many Retail Stores in Japan? Japan and the World Economy, 2, 365-386.

Gabszewicz, Jean Jaskold and Jacques-Francois Thisse (1986). "Spatial Competition and the Location of Firms," in J. Gabszewicz et al., Location Theory, Harwood Academic Publisher, New York, pp. 1-7.

Heal, Geoffrey (1980), "Spatial Structure in the Retail Trade: A Study in Product Differentiation with Increasing Returns," The Bell Journal of Economics, vol. 11, pp. 565-583.

Maruyama, Masayoshi; Kyohei Sakai; Yoko Togawa; Nobuo Sakamoto; Michio Yamashita; Masaharu Arakawa; and Hiroyuki Ijo (1991). "Nihon no ryutsu shisutemu: riron to jissho" (the distribution system of Japan: theory and empirics) keizai bunseki, no. 123 (May).

McCraw, Thomas K. and Patricia O'Brien (1986). "Production and Distribution: Competition Policy and Industry Structure", in Thomas K. McCraw, ed., America versus Japan: A Comparative Study, Boston: Harvard Business School Press, pp. 77-86.

Nariu, Tatsuhiko and David Flath (forthcoming). "The Complexity of Wholesale Distribution Channels in Japan," in Michael R. Czinkota and Masaaki Kotabe, eds., The Japanese Distribution System Handbook, Chicago: Probus Publishing Company.

Patrick, Hugh T. and Thomas P. Rholen (1987). "Small-scale Family Enterprises," in Kozo Yamamura and Yasukichi Yasuba, eds., The Political Economy of Japan, Volume 1: The Domestic Transformation, Stanford U. Press, pp. 331-384.

Theil, Henri (1971). Principles of Econometrics, New York: John Wiley \& Sons, Inc. 
Table 1. Variables.

\begin{tabular}{|c|c|c|c|c|}
\hline $\begin{array}{l}\text { variable } \\
\text { name }\end{array}$ & description & source $^{a}$ & $\begin{array}{l}\text { year of } \\
\text { observ- } \\
\text { at ion }\end{array}$ & $\begin{array}{l}\text { mean } \\
(s . d)\end{array}$ \\
\hline LSTORES & $\begin{array}{l}\text { natural logarithm of } \\
\text { retail stores per } \\
\text { thousand persons }\end{array}$ & UN, M & $1975-87$ & $\begin{array}{c}2.09 \\
(0.29)\end{array}$ \\
\hline$\ddot{L P O P} / K M 2$ & $\begin{array}{l}\text { naturai iogarithm of } \\
\text { population per } .01 \mathrm{~km}^{2}\end{array}$ & $\ddot{U N}$ & 1903 & $\begin{array}{l}-0.53 \\
-0.53 \\
(1.78)\end{array}$ \\
\hline$\ddot{L} \ddot{F} \angle O O O R S P$ & $\begin{array}{l}\text { natura logarithm of } \\
\text { dwelling floorspace } \\
\text { in } \mathrm{m}^{2} \text { per person }\end{array}$ & $\ddot{u N}, \ddot{s} \dot{S}$ & $1982-83$ & $\begin{array}{c}0.02 \\
(0.21)\end{array}$ \\
\hline$\ddot{L} \ddot{E} \ddot{N G} \ddot{G H}$ & $\begin{array}{l}\text { naturai logarithm of } \\
\text { square root of } \\
\text { country land area } \\
\text { measured in } \mathrm{km}^{2}\end{array}$ & UN & 1983 & $\begin{array}{l}2.78 \\
(1.07)\end{array}$ \\
\hline$\ddot{L C A R S}$ & $\begin{array}{l}\text { natura iogarithm of } \\
\text { private automobiles } \\
\text { per person }\end{array}$ & un & 1983 & $\begin{array}{l}-1.91 \\
(1.29)\end{array}$ \\
\hline LTRUCKS & $\begin{array}{l}\text { natural logarithm of } \\
\text { commercial vehicles } \\
\text { per person }\end{array}$ & $\ddot{u N}$ & $1981-83$ & $\begin{array}{l}-3.34 \\
(0.84)\end{array}$ \\
\hline
\end{tabular}

${ }^{a}$ UN = United Nations Statistical Yearbook (1983/84), Table 18 (population, land area), Table 158 (retail stores), Table 172 (private and comercial vehicles), Table 157 (floorspace of existing or newly constructed dwellings).

$M=$ Maruyama, Masayoshi; Kyohei Sakai; Yoko Togawa; Nobuo Sakamoto; Michio Yamashita; Masaharu Arakawa; and Hiroyuki Ijo (1991). "Nihon no ryutsu shisutemu: riron to jissho" (the distribution system of Japan: theory and empirics) keizai bunseki, no. 123 (May), Table 1-1, p. 7. (original sources: France, Enquete D'Etablissment Dans Le Commerce, 1982; W. Germany, Handels-und Gaststattenzahlung, 1985; UK, Business Monitor, SD025, Retailing, 1982; US, 1987 Census of Retail Trade.)

SS = Seifu shiryo nado fukyu chosa-kai, gekkan seifu shiryo (association of surveys of data such as disseminated by governments, monthly report of government data) no. 203,1991, p. 27. 
Table 2. OLS regression estimate; dependent variable = LSTORES, natural logarithm of number of stores per person.

\begin{tabular}{|c|c|c|}
\hline \multirow[b]{2}{*}{ Variable } & \multicolumn{2}{|c|}{ Coefficents and t-statistics } \\
\hline & Ful1 sample & Japan excluded \\
\hline Intercept & $\begin{array}{c}3.34 \\
(12.68)\end{array}$ & $\begin{array}{c}3.25 \\
(10.43)\end{array}$ \\
\hline$\ddot{L P O P} / K M 2 M \cdots$ & $\begin{array}{c}\cdots \\
\quad-0.07 \\
(-2.12)\end{array}$ & $\begin{aligned} \cdots & 0.07 \\
& (-2.12)\end{aligned}$ \\
\hline$\ddot{L} \ddot{F L O O O R S} \ddot{P}^{\cdots \cdots}$ & $\begin{aligned} \cdots & \cdots \\
& -1.02 \\
& (-4.57)\end{aligned}$ & $\begin{array}{c}\cdots \\
\quad-0.97 \\
(-3.82)\end{array}$ \\
\hline$\ddot{L L E N G T H} \ddot{H} \cdots \cdot$ & $\begin{aligned} \cdots \cdots & \cdots \\
& -0.11 \\
& (-2.12)\end{aligned}$ & $\begin{array}{c}\cdots \cdots \\
\quad-0.12 \\
(-2.10)\end{array}$ \\
\hline$\ddot{L} \ddot{C A R S} \cdots \cdots \cdots$ & $\begin{aligned} \cdots \cdots & \cdots \\
& -0.17 \\
& (-3.42)\end{aligned}$ & $\begin{array}{c}\cdots .10 \\
-0.16 \\
(-2.85)\end{array}$ \\
\hline$\ddot{L T R U C K S}{ }^{\cdots \cdots}$ & $\begin{array}{r}0.38 \\
\\
(4.92)\end{array}$ & $\begin{aligned} & \cdots \cdots \\
& 0.35 \\
&(3.56)\end{aligned}$ \\
\hline $\operatorname{adj} R^{2}$ & 0.65 & 0.53 \\
\hline$\cdots \cdots$ & $\cdots \cdots{ }_{6.93} \cdots \cdots \cdot$ & $\cdots \ddot{4.36}$ \\
\hline$\dot{s} \cdots \cdots \cdots \cdots \cdot$ & $\cdots \cdots \ddot{0}_{0.173} \cdots \cdots \cdot$ & 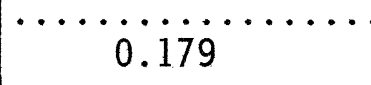 \\
\hline$\ddot{n} \cdots \cdots \cdots \cdots$ & $\cdots \ddot{1}_{17} \cdots \cdot$ & $\cdots \cdots \cdots \cdots$ \\
\hline
\end{tabular}


Appendix. Selected data. ${ }^{a}$

\begin{tabular}{|c|c|c|c|c|c|c|}
\hline & STORES & POP/KM2 & FLOORSP & LENGTH & CARS & TRUCKS \\
\hline Country & $\begin{array}{l}\text { Retail } \\
\text { stores per } \\
\text { thousand } \\
\text { persons } \\
\text { (excl. } \\
\text { eating and } \\
\text { drink ing } \\
\text { estab1.) }\end{array}$ & $\begin{array}{l}\text { Population } \\
\text { density } \\
\text { (units }= \\
\text { hundred } \\
\text { persons } \\
\text { per } \mathrm{km}^{2} \text { ) }\end{array}$ & $\begin{array}{l}\text { Floorspace } \\
\text { of private } \\
\text { dwe11ings } \\
\text { per person } \\
\text { (units }=m^{2} \\
\text { per } \\
\text { person) }\end{array}$ & $\begin{array}{l}\text { Square } \\
\text { root of } \\
\text { land area } \\
\text { of country } \\
\text { (units=km) }\end{array}$ & $\begin{array}{l}\text { Private } \\
\text { vehicles } \\
\text { per person }\end{array}$ & $\begin{array}{l}\text { Commercial } \\
\text { vehicles } \\
\text { per person }\end{array}$ \\
\hline Brazil & 6.68080 & 0.16 & 0.919 & 92.260 & 0.071 & 0.014 \\
\hline Ecuador & 8.676 & 0.25 & 1.238 & 33.749 & 0.010 & 0.01881 \\
\hline Finland & $7.410_{82}$ & 0.14 & 0.864 & 18.358 & 0.289 & 0.036 \\
\hline Greece & $16.229 \quad 78$ & 0.75 & 0.796 & 11.485 & 0.108 & 0.056 \\
\hline Iceland & $7.954 \quad 82$ & 0.02 & 1.306 & 10.149 & 0.402 & 0.050 \\
\hline Ireland & $9.146 \quad 77$ & 0.50 & 0.98382 & 8.385 & 0.205 & 0.021 \\
\hline JAPAN & $14.340 \quad 82$ & 3.18 & 0.835 & 19.435 & 0.220 & 0.131 \\
\hline Netherlands & 6.223 & 3.53 & 1.16782 & 6.387 & 0.328 & 0.025 \\
\hline New Zea land & 9.345 & 0.12 & 1.251 & 16.392 & 0.438 & 0.089 \\
\hline Norway & 8.211 & 0.13 & 0.95382 & 18.499 & 0.334 & 0.047 \\
\hline Singapore & $6.507 \quad 81$ & 43.53 & 1.430 & 0.775 & 0.086 & 0.045 \\
\hline Syria & $7.637 \quad 75$ & 0.54 & 0.871 & 13.609 & 0.013 & 0.011 \\
\hline Turkey & 5.84380 & 0.62 & 1.045 & 27.939 & 0.018 & 0.007 \\
\hline France & $10.300 \quad 82$ & 1.00 & 0.823 & 23.958 & 0.351 & 0.05482 \\
\hline W. Germany & 6.600 & 2.46 & 0.800 & 15.764 & 0.402 & 0.026 \\
\hline U.K. & $6.200 \quad 82$ & 2.28 & 0.950 & 15.620 & 0.286 & 0.041 \\
\hline U.S. & $6.100_{87}$ & 0.19 & 1.536 & 96.812 & 0.535 & 0.157 \\
\hline
\end{tabular}

a Year of observation is 1983 unless otherwise indicated. See footnotes to Table 1 for sources. 